\title{
Experimental methods of evaluating measurement uncertainty resulting from sample collection and preparation for analysis in chemical laboratories

\author{
Niepewność pomiaru wynikająca z poboru i przygotowania próbek do
} badań w laboratorium chemicznym oszacowana metoda doświadczalna
}

\author{
* Dr inż. Mieczysława Giercuszkiewicz-Bajtlik, prof. dr hab. Barbara Gworek, \\ Institute of Environmental Protection - National Research Institute, Krucza \\ 5/11d St., 00-548 Warsaw, phone: +48 22 3750525, e-mail: mbajtlik@ios. \\ edu.pl, barbara.gworek@ios.edu.pl
}

Keywords: measurement uncertainty, sample heterogeneity, experimental method, method validation, method accuracy, method precision, certified material

Słowa kluczowe: niepewność pomiaru, niejednorodność próbki, metoda doświadczalna, walidacja metody, dokładność metody, precyzja metody, certyfikowane materiały

\begin{abstract}
A measurement result should be presented with its measurement uncertainty determined according to the evaluation method. The paper presents an experimental method used to evaluate measurement uncertainty resulting from the collection and preparation of samples for analysis in chemical labs. Evaluation of measurement uncertainty of the content of particular elements in actual samples has been conducted with the method of precision determination using ROBUST ANOVA analysis of variance. Analyses of soil samples were made in the Laboratory of the Institute of Environmental Protection - National Research Institute.

The experimental method of evaluating measurement uncertainty allows a fast and relatively simple evaluation of all sources of uncertainty resulting from sample collection and preparation for analysis in chemical labs.
\end{abstract}

(c) IOŚ-PIB

\section{INTRODUCTION}

A measurement result is considered reliable only when it is presented along with its uncertainty evaluated according to a relevant procedure [Bulska, Taylor 2003]. Presentation of measurement uncertainty provides evidence that the laboratory works according to internationally recognised standards. Knowledge of the uncertainty values ascribed to the obtained results is an indispensable step in comparing data among particular labs, clients and institutions that utilise the measurement findings [Giercuszkiewicz-Bajtlik, Gworek 2009]. The ability of correct calculation of uncertainty has become an indispensable tool in everyday practice of an analyst [Bulska 2007]. The EURACHEM/CITAC Guide (2007) and the NORDTEST TR 537 Textbook (2008) indicate that the sampling process may have significant influence on the total uncertainty of the measurement result. The paper presents an experimental method of evaluating measurement uncertainty resulting from collection and preparation of samples for analysis. Real samples collected and prepared for analysis according to the procedure were subject to precision evaluation with application of ANOVA analysis of variance for various uncertainty sources. Results of experimental evaluation of measurement

\section{Streszczenie}

W artykule przedstawiono metodę doświadczalną szacowania niepewności wyniku pomiaru związanej z poborem i przygotowaniem próbek do badań w laboratorium chemicznym.

Szacowania niepewności wyników pomiaru zawartości pierwiastków w próbkach rzeczywistych dokonano metodą oznaczania precyzji z użyciem analizy wariancji ROBUST ANOVA. Przykładowe badania próbek gleby prowadzone były w Laboratorium Instytutu Ochrony Środowiska - Państwowego Instytutu Badawczego.

Metoda doświadczalna szacowania niepewności wyników pomiaru pozwala na szybkie i stosunkowo proste szacowanie wszystkich źródeł niepewności dotyczących pobierania i przygotowania próbek do badań w laboratorium chemicznym. uncertainty linked with collection and preparation of samples for analysis with application of ROBUST ANOVA analysis of variance have been presented at the National Scientific Conference "Quality in Analytical Chemistry" in Warsaw in 2011 [Dąbrowski, Mróz 2011].

\section{PROCEDURE OF EXPERIMENTAL EVALUATION OF MEASUREMENT UNCERTAINTY RESULTING FROM COLLECTION AND PREPARATION OF SAMPLES FOR ANALYSIS}

The studies should refer to evaluating measurement uncertainty resulting from the preparation of samples for analysis (along with sample collection) using an experimental method.

\subsection{Preparation of samples for analytic studies}

- Two parallel environmental samples are collected in each site in the field. 
- Both environmental samples undergo physical preparation that allows obtaining two analytical samples from each environmental sample.

- Two measurement samples are collected from each analytical sample; each of them is analysed twice (according to the presented scheme 1). Each environmental sample is prepared independently for the analysis.

- The scheme of double sample collection and double chemical analysis is known as the sustainable project; it encompasses the stage from the sample collection in the field to the laboratory sample.

Literature data indicate that material impurity belongs to one of the most important factors influencing inconsistency linked with sample collection [EURACHEM/CITAC Guide 2007]. The supplied samples should be uniform. They are purified from organic wastes such as plant remains, paper and rocks. Next, they are mixed thoroughly and part of them (depending on the quantity) is arrayed onto trays. The material is air-dried in a ventilated room and prepared according to the procedure requirements. Laboratory samples prepared in this way are stored in sealed polyethylene containers [Ostrowska et al 1991].

\subsection{Studies of the content of elements in} environmental samples with application of ROBUST ANOVA analysis of variance for the evaluation of measurement uncertainty resulting from collection and preparation of samples for analysis

It is indispensable to assure quality during sample collection and analysis [Pasławski 2011]:

- precision should be estimated using analysis of variance (ANOVA) for various sources of uncertainty;
- the laboratory should document the application of certified CRM materials for the studied matrix, relevant methodology, relevant determinations and content;

- once a year the laboratory should check the current validation for each method;

- the measurement device should be calibrated prior to the measurements of each series of the studied samples.

The accredited Institute of Environmental Protection - National Research Institute (IEP - NRI) Laboratory possesses a documented application of proper certification materials for a relevant matrix, relevant methodology, relevant determinations and concentrations. The measuring laboratory accessories of the IEP - NRI Laboratory are calibrated before each series of measurements.

\section{EXEMPLARY STUDIES EVALUATING MEASUREMENT UNCERTAINTY RESULTING FROM THE COLLECION AND PREPARATION OF SAMPLES FOR ANALYSIS OF THE MERCURY CONTENT IN SOIL SAMPLES WITH APPLICATION OF ROBUST ANOVA ANALYSIS OF VARIANCE}

3.1. Validation of the procedure of mercury determination in solid soil samples with application of the AMA-254 automatic analyser

Mercury determination with application of the AMA-254 mercury analyser in environmental samples such as air, rainfall, soil, plants and food products in the IEP - NRI Laboratory was conducted ac-

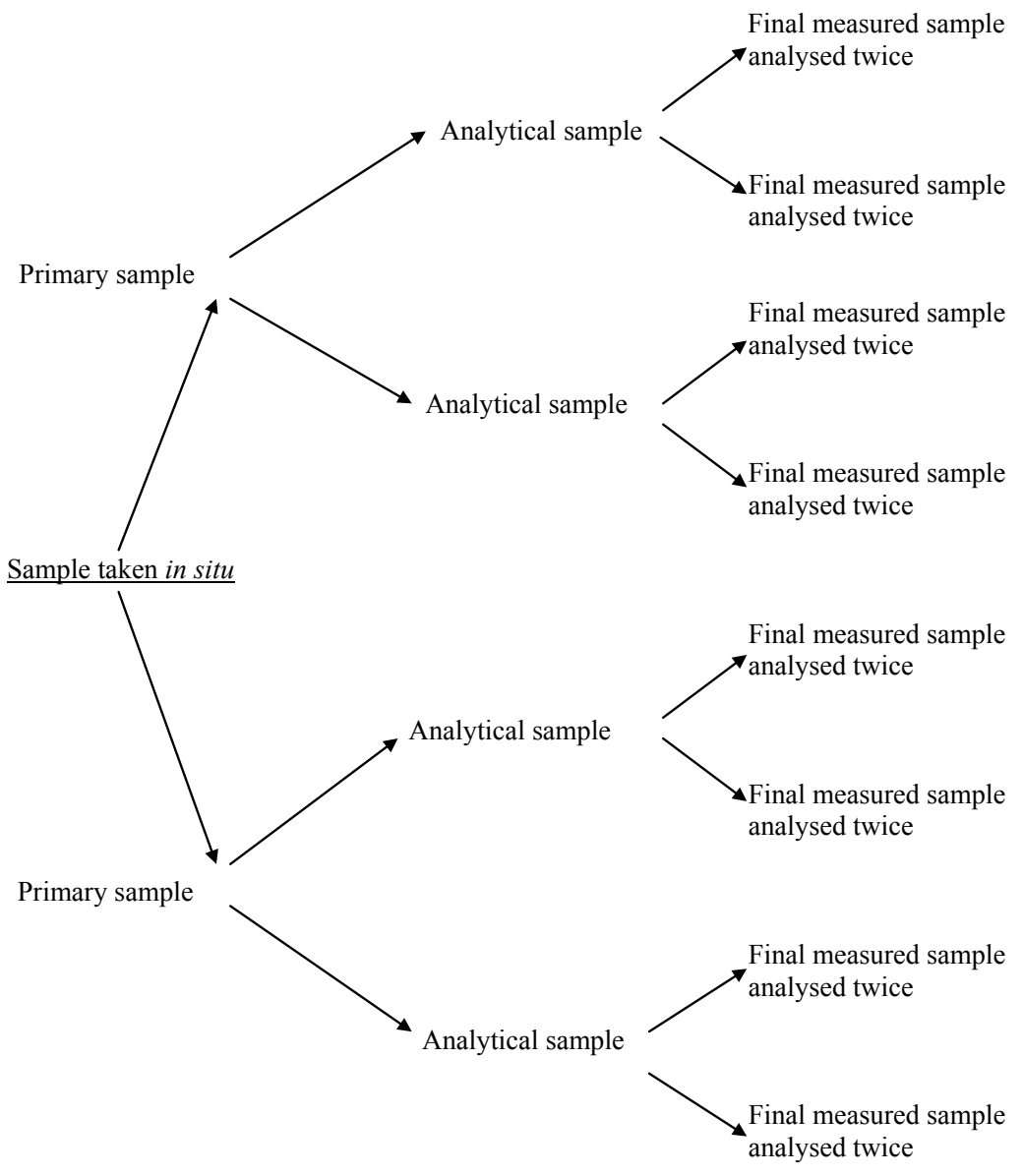

Scheme 1. Sample preparation for studies of measurement uncertainty using the experimental method. 
cording to relevant procedures. It is worth noting that mercury often occurs in trace quantities close to the detection limit $(0.01 \mathrm{ng} \mathrm{Hg})$ in environmental samples. Therefore, calibration of the AMA-254 automatic analyser was made in reference solutions already at the level of $0.02 \mathrm{ng} \mathrm{Hg}$ for the first calibration range.

Two certified reference soil materials were applied in the statistic analysis in order to determine the validation parameters of the procedure of mercury determination using the AMA-254 automatic analyser:

- Soils Reference Material RTH 912 at concentration $0.11 \mathrm{mg} / \mathrm{kg}$ \pm 0.02 and

- Soils Reference Material RTH 907 at concentration $1.13 \mathrm{mg} / \mathrm{kg}$ \pm 0.13 .

Based on the results obtained, the following parameters were calculated: method accuracy, method precision and result uncertainty for the two certified reference soil materials (Table 1).

\subsection{Evaluation of measurement uncertainty}

resulting from sample collection and preparation

for analysis using the experimental method

Uncertainty resulting from the collection and preparation of samples for analysis has been evaluated using the ROBUST ANOVA analysis of variance conducted on the basis of data from the sustainable experimental analysis of the mercury content in soil samples (Table 2)

\subsection{Results of ROBUST ANOVA analysis of variance} of evaluating complex standard uncertainty

The ANOVA analysis of variance was conducted based on data from the sustainable experimental project measuring the content of mercury in the soil samples.

In the ROBUST ANOVA analysis of variance, the complex standard uncertainty of the mercury content in real samples was referred to:

- uncertainty resulting from the preparation of samples for analysis, experimentally evaluated using the ROBUST ANOVA resistance analysis of variance;

- -standard uncertainty $U_{S}\left(x_{i}\right)$ - standard uncertainty of the results of measurement $x_{i}$ expressed as standard deviation (SD).

$$
U_{S}\left(x_{i}\right)=S D
$$

where

$$
S D=\sqrt{\frac{\sum_{i-1}^{n}\left(x_{n}-A_{v}\right)^{2}}{n-1}}
$$

$\mathrm{n}$ - number of measurements;

$A_{v}$ - arithmetic mean of measurement results;

$\mathrm{x}_{\mathrm{n}}-\mathrm{nth}$ measurement result.
- uncertainty resulting from the analysis evaluated using linear adjustment of the standard curve using the least squares fitting, according to the following formulas:

- absorbance A

Two series of absorbance measurements for standard solutions were conducted. Two standard curves with the following general formula were obtained (EURACHEM/CITAC 2000):

$$
\mathrm{A}=\mathrm{B}_{1} \cdot \mathrm{C}_{\mathrm{i}}+\mathrm{Bo}
$$

- uncertainty $\mathrm{U}_{\mathrm{s}}\left(\mathrm{c}_{\mathrm{o}}\right)$

$$
U_{S}\left(c_{O}\right)=\frac{S D}{B_{1 s} r} \sqrt{\frac{1}{p}+\frac{1}{n}+\frac{\left(c_{O}-\bar{c}\right)^{2}}{S D_{x x}}}
$$

with the remnant standard deviation (SD) calculated according to the formula:

$$
S D=\sqrt{\sum_{j=1}^{n}\left[A_{j}-\left(B_{O}+B_{1} \cdot c_{j}\right)\right]^{2}}
$$

and

$$
\mathrm{SD}_{\mathrm{Xx}}=\sum_{\mathrm{j}=1}^{\mathrm{n}}\left(\mathrm{c}_{\mathrm{j}}-\overline{\mathrm{c}}\right)^{2}
$$

where

A - absorbance;

$A_{j}-j$ th measurement of the area measurement for the peak of the ith standard solution;

$\mathrm{C}_{i}-$ concentration of the ith standard solution;

$B_{1}$ - curve slope coefficient;

$\mathrm{B}_{0}$ - coefficient of curve transection with the vertical axis,

$\mathrm{SD}$ - standard deviation;

$p$ - number of determined measurements;

$\mathrm{n}$ - number of standardised measurements;

$\mathrm{C}_{0}-$ content of studied component in a real sample;

$\mathrm{C}^{-}-$mean concentration of standard solutions;

$i$ - indicator of the standard number of the calibrating solution;

$j$ - number of the subsequent measurement determining the stan-

\begin{tabular}{|c|c|c|c|}
\hline$\frac{\text { Results of classical ANO }}{\text { horizon exceeding } 0.011}$ & $\frac{\text { analysis of variance for the obje }}{40 \mathrm{mg} \mathrm{Hg} / \mathrm{kg}}$ & e mercury & al samples of th \\
\hline Mean $=$ & 0.025 & & \\
\hline Standard deviation (mea & 0.001 & & \\
\hline Variance [ \% ] & 6.812 & & \\
\hline ROBUST ANOVA & & & \\
\hline & $\begin{array}{l}\text { Collection and } \\
\text { preparation of samples }\end{array}$ & Analysis & Measurement \\
\hline Standard deviation & & & \\
\hline $\begin{array}{l}\text { Standard uncertainty of } \\
\text { measurement result }\end{array}$ & 0.0408 & 0.1569 & 0.162 \\
\hline Extended uncertainty & 0.0770 & 0.3121 & 0.324 \\
\hline
\end{tabular}
dard curve.

- complex standard uncertainty of the measurement as the sum of squares of relative standard uncertainty calculated according to the following formula:

$$
U_{\text {means }}=\sqrt{U_{\text {sampl }}^{2}+U_{\text {anal }}^{2}}
$$




\subsection{Results of exemplary studies evaluating} measurement uncertainty

Exemplary studies of the collected measurement soil samples were carried out in the Laboratory of the IEP - NRI, accredited by the Polish Accreditation Centre, with an implemented management system with internal and external quality control in the following ranges:

- organic and inorganic carbon analysis, with application of the SSM-5000A automatic carbon analyser with add-on;

- determination of the mercury content, with application of the AMA-254 automatic analyser;

- determination of the elemental content, with application of ICPAES spectroscopy.

Results of the ROBUST ANOVA analysis of variance of evaluating uncertainty of measuring elements in soil samples using the experimental method have been presented in Table 3.

\subsection{Comparison of the results of evaluating}

the measurement uncertainty of solid samples using the statistic method and the experimental method

To emphasise the positive features of the experimental method in uncertainty evaluation with regard to the interpretation and presentation of the analysis results, Table 4 shows the comparison of evaluated measurement uncertainties using the statistic and experimental methods for the following elements:

- C total carbon, using the automatic TOC analyser with the SSM-5000 A add-on;

- Hg mercury, using the AMA-254 automatic analyser

\section{SUMMARY}

The paper presents the system of double sampling and double chemical analysis, known as a sustainable experimental project, which includes stages from sample collection in the field to a laboratory sample. This project is the basis for the procedure of experimental evaluation of complex standard uncertainty resulting from the collection and preparation of samples for analysis.

Based on data from the sustainable experimental project, the classic ROBUST ANOVA analysis of variance was conducted for results of the contents in environmental soil samples of the following elements: mercury $(\mathrm{Hg})$, zinc $(\mathrm{Zn})$, lead $(\mathrm{Pb})$, nickel $(\mathrm{Ni})$, copper $(\mathrm{Cu})$, chromium $(\mathrm{Cr})$, cadmium $(\mathrm{Cd})$, sulphur $(\mathrm{S})$, phosphorus $(\mathrm{P})$, sodium $(\mathrm{Na})$, manganese $(\mathrm{Mn})$, magnesium $(\mathrm{Mg})$, potassium $(\mathrm{K})$, iron $(\mathrm{Fe})$ and coal $(\mathrm{C})$ in order to evaluate the uncertainty resulting from sample collection and preparation for analysis. The studies were conducted for samples from the mineral soil horizon.

The results indicate a high precision of evaluating the measurements using the experimental method (Tables 3 and 4). This method of evaluating measurement uncertainty allows a fast and relatively simple assessment of all uncertainty sources resulting from collection and preparation of samples for analysis. Evaluation of uncertainty resulting from the collection and preparation of a sample for analysis may be quantitative only through measurements on environmental samples. The results of the studies will be introduced in the Laboratory of Environmental Monitoring of IEP $\mathrm{NRI}$ and will become the base of uncertainty budget of the analysis results of the studied elements in soil samples.

Table 1. Collective presentation of parameters validating the method of mercury determination in the soil materials.

\begin{tabular}{|l|l|l|l|}
\hline No. & Method parameters & $\begin{array}{l}\text { Reference } \\
\text { RTH } 912\end{array}$ & $\begin{array}{l}\text { Reference } \\
\text { RTH } 907\end{array}$ \\
\hline 1 & Precision of $\mathrm{mg} \mathrm{Hg} / \mathrm{kg}$ & 0.005 & 0.107 \\
\hline 2 & Precision $\%$ & 8.57 & 2.05 \\
\hline 3 & Uncertainty of $\mathrm{mg} \mathrm{Hg} / \mathrm{kg}$ results & 0.009 & 0.023 \\
\hline 4 & Detection limit $\mathrm{ng} \mathrm{Hg}$ & 0.01 & \\
\hline
\end{tabular}

Table 2. Classical ROBUST ANOVA analysis of variance based on the results of the mercury content determined by the automatic mercury analyser AMA-254 in samples from the mineral soil horizon for experimental evaluation of measurement uncertainty caused by collection and preparation of samples - range of mercury content $0.011-0.040 \mathrm{mg} \mathrm{Hg} / \mathrm{kg}$.

\begin{tabular}{|c|c|c|c|c|c|c|c|c|c|c|c|}
\hline \multirow{3}{*}{$\begin{array}{l}\begin{array}{l}\text { No. of } \\
\text { sample }\end{array} \\
\text { 17/29 }\end{array}$} & \multicolumn{8}{|c|}{ Double field samples } & \multirow{2}{*}{$\begin{array}{c}\text { Arithmetic } \\
\text { mean } \\
\text { Av }\end{array}$} & \multirow{2}{*}{ Variance } & \multirow{2}{*}{$\begin{array}{c}\text { Standard } \\
\text { deviation } \\
\text { (SD) }\end{array}$} \\
\hline & \multicolumn{8}{|c|}{$\mathrm{Hg}$ (mercury) content in soil samples ( $\mathrm{mg} \cdot \mathrm{kg}^{-1}$ dry mass) } & & & \\
\hline & 0.037 & 0.037 & 0.037 & 0.037 & 0.036 & 0.036 & 0.040 & 0.039 & 0.037 & 1.734 & 0.0014 \\
\hline $19 / 28$ & 0.032 & 0.031 & 0.031 & 0.031 & 0.028 & 0.028 & 0.028 & 0.029 & 0.029 & 2.109 & 0.0016 \\
\hline $22 / 36$ & 0.012 & 0.012 & 0.012 & 0.012 & 0.012 & 0.012 & 0.011 & 0.012 & 0.012 & 1.094 & 0.0004 \\
\hline \multirow[t]{2}{*}{$25 / 18$} & 0.013 & 0.013 & 0.013 & 0.013 & 0.014 & 0.013 & 0.014 & 0.013 & 0.013 & 1.875 & 0.0005 \\
\hline & & & & & & & & & Mean 0.025 & $\sum 6.812$ & Mean 0.001 \\
\hline
\end{tabular}


Table 3. Results of ROBUST ANOVA analysis of variance of evaluating uncertainty of measuring elements in soil samples using the experimental method.

\begin{tabular}{|c|c|c|}
\hline \multirow{3}{*}{ Determined elements } & \multicolumn{2}{|c|}{ Analysed samples } \\
\hline & \multicolumn{2}{|c|}{ Mineral soil horizon } \\
\hline & Content & Extended uncertainty \\
\hline $\mathrm{Hg}$ & $0.1120 \mathrm{mg} \mathrm{Hg} / \mathrm{kg}$ & 0.3240 \\
\hline $\mathrm{Zn}$ & $16.5120 \mathrm{mg} \mathrm{Zn/kg}$ & 0.0779 \\
\hline $\mathrm{Pb}$ & $9.3690 \mathrm{mg} \mathrm{Pb} / \mathrm{kg}$ & 0.1392 \\
\hline $\mathrm{Na}$ & $82.4600 \mathrm{mg} \mathrm{Na} / \mathrm{kg}$ & 0.2350 \\
\hline $\mathrm{Mn}$ & $338.0500 \mathrm{mg} \mathrm{Mn} / \mathrm{kg}$ & 0.0770 \\
\hline $\mathrm{Mg}$ & $582.0900 \mathrm{mg} \mathrm{Mg} / \mathrm{kg}$ & 0.0811 \\
\hline $\mathrm{K}$ & $560.2800 \mathrm{mg} \mathrm{K} / \mathrm{kg}$ & 0.1482 \\
\hline $\mathrm{Fe}$ & $4919.2300 \mathrm{mg} \mathrm{Fe} / \mathrm{kg}$ & 0.0688 \\
\hline C & $0.0120 \mathrm{mg} \mathrm{C} / \mathrm{kg}$ & 0.1900 \\
\hline
\end{tabular}

Table 4. Methods of evaluating measurement uncertainty of stable samples.

\begin{tabular}{|c|c|c|}
\hline & \multicolumn{2}{|c|}{ Evaluated measurement uncertainty } \\
\hline Determined element & Statistic method & Experimental method \\
\hline $\begin{array}{c}\text { C total carbon with use of } \\
\text { automatic analyser }\end{array}$ & 0.228 & 0.19 \\
\hline $\begin{array}{c}\text { Hg mercury with use of AMA-254 } \\
\text { automatic analyser }\end{array}$ & 0.14 & 0.324 \\
\hline
\end{tabular}

\section{REFERENCES}

BULSKA E. 2007. Pobieranie próbek kontrowersyjny element budżetu niepewności. [Sample collection - a controversial element of the uncertainty budget]. Analityka Nauka i Praktyka 1: 41-45.

BULSKA E., TAYLOR P.D.P. 2003. On the importance of metrology in chemistry in New Horizons and Challenge in Environmental Analysis and Monitoring. Ed. Namiśnik J., Chanowski W., Żmijewska P., by Centre of Excellence in Environmental Analysis and Monitoring, Chapter 4, 42-57, ISBN: 83-91908100.

DĄBROWSKI R., MRÓZ A. 2011. Metrologiczne aspekty pobierania próbek środowiskowych [Metrological aspects of collecting environmental samples]. Ogólnopolska Konferencja Naukowa Jakość w chemii analitycznej, Warszawa, 22.

EURACHEM/CITAC 2000- Guide. Quantifying Uncertainty in Analytical Measurement. QUAM P1.

Guide to the Expression of Uncertainty in Measurement 1995. First Edition 1993. Przewodnik GUM 1999.

GIERCUSZKIEWICZ-BAJTLIK M., GWOREK B. 2009. Metody wyrażania niepewności pomiaru w analizie chemicznej próbek środowiskowych. [Methods of expressing measurement uncer- tainty in chemical analysis of environmental samples]. Ochrona środowiska i zasobów naturalnych nr 39, IOŚ.

PASŁAWSKI P. 2011. Zapewnienie jakości w pobieraniu próbek. Elementy sterowania jakością wg norm i opracowań renomowanych organizacji międzynarodowych. [Assertion of quality in sample collection. Elements of quality steering according to norms and reports of renown international organizations]. Spotkanie PCA z laboratoriami akredytowanymi. 20 październik, Warszawa.

Podręcznik obliczania niepewności pomiaru w laboratoriach środowiskowych NORDTEST TR 537. Wersja 3 [Handbook for calculation measurement uncertainty in environmental laboratories NORDTEST TR 537, Version 3]. 2008.

Przewodnik EURACHEM/ CITAC 2007. Niepewność pomiaru związana z pobieraniem próbek. Przewodnik metodyczny. [EURACHEM/CITAC Guide 2007. Quantifying uncertainty in analytical measurement]. Biuletyn Informacyjny Klubu POLLAB 1/52/2009.

OSTROWSKAA., GAWLIŃSKI S., SZCZUBIAŁKA Z. 1991. Metody analizy i oceny właściwości gleb i roślin. Katalog. [Methods of analysing and evaluating soil and plant properties. A catalogue]. IOŚ. 